\title{
Weed Management in Vegetable Cluster Bean (Cyamopsis tetragonoloba)
}

\author{
Dinesh K. Yadav ${ }^{*}$, P. Deewan ${ }^{2}$, Yogendra Meena ${ }^{3}$, Deepak Gupta ${ }^{4}$, \\ S. M. Yadav ${ }^{5}$ and Manju Netwal ${ }^{1}$ \\ ${ }^{1}$ Department of Horticulture, ${ }^{4}$ Department of PBG, Sri Karan Narendra Agriculture \\ University, Jobner, Rajasthan (India) \\ ${ }^{2}$ Agriculture Research Sub Station, ${ }^{3}$ Krishi Vigyan Kendra, Kotputli, India \\ ${ }^{5} \mathrm{KVK}$, Gonera, India \\ *Corresponding author
}

\section{Keywords}

Cluster bean, Herbicide, Hand weeding, Yield

\section{Article Info}

Accepted:

20 January 2021

Available Online:

10 February 2021
A field experiment was conducted during kharif season of 2017 and 2018 at Agriculture Research Sub Station, Kotputli, Jaipur, where four herbicides either as integrated with hand weeding or sequentially applied were evaluated for efficacies of the herbicides on controlling weeds, their influences on green pod yield of vegetable cluster bean in randomized block design with four replications. The results of two-year experimentation indicated that all the weed control treatment gave significantly minimum dry weight of weed and higher green pod yield over no weeding. In pooled data based on both the years, the treatment of weed free check was found highest value of green pod yield $(44.53 \mathrm{q} / \mathrm{ha})$. It was found at par with two hand weeding at 20 and $40 \mathrm{DAS}(44.06 \mathrm{q} / \mathrm{ha}$ ), Pendimethalin @ $1.0 \mathrm{~kg}$ ai. /ha as pre-emergence \& one hand weeding at 25 DAS (43.41 q/ha) and Imazathyper 10 SL@ $40 \mathrm{~g}$ ai. /ha at 15-20 DAS (42.98 q/ha). Highest weed control efficiency and minimum weed index were observed in weed free check. Among various herbicides treatments, Imazathyper 10 SL@ $40 \mathrm{~g}$ ai. /ha at 15-20 DAS showed highest B:C ratio in both the years and it was significant differ over the rest of treatments. In monetary term imazathyper 10 SL@40 g ai. /ha recorded higher net return (Rs.85948/ha) and benefit: cost ratio (3.0) over weed free check (Rs.79590/ha and 2.47, respectively)

\section{Introduction}

Cluster bean (Cyamopsis tetragonoloba) commonly known as guar crop, is a drought and high temperature tolerant, deep rooted, summer annual legume of high social and economic significance. Guar has experienced a remarkable journey from a traditional crop grown on marginal lands mainly for food, animal feed and fodder to a crop with various industrial usages ranging from textile, food processing, cosmetics, mining, explosive, oil and pharmaceutical industries, printing, toilet goods etc. India is the largest producer of guar and contributes $80 \%$ of total guar production in the world. India is the major exporter of guargum to the world; it exports various forms of Guar products to a large number of 
countries. The country has exported $3,81,880.16$ MT of guargum to the world for the worth of Rs. 3,261.60 crores/456.96 USD Millions during the year 2019-20 (Anonymous, 2020). During last three years, guar gum had topped the list of India's top agricultural export commodity in terms of value (Anonymous 2015). The significantly higher prices of guar in recent time have helped expand the crop to non-traditional regions and seasons.

In India, cluster bean is mostly grown in Rajasthan, Haryana, Punjab, Uttar Pradesh and Madhya Pradesh. Rajasthan occupies first position in India both in area and production. It accounts for almost 82.1 per cent area and $70 \%$ production in India. Haryana and Gujarat have second and third position respectively. Rajasthan has an area of 46.30 lakh hectare, production of $27.47 \mathrm{M}$ tones with a productivity of $593 \mathrm{~kg} / \mathrm{ha}$. (Anonymous, 2015). In Rajasthan, guar is mainly grown in Barmer, Churu, Sriganganagar, Nagaur, Jalore, Sikar, Jaisalmer, Bikaner, Jaipur, Jhunjhunu and Alwar districts. Cluster bean occupies a significant place at the national level as well as the state level. India is the leading exporter of guar seed and guar gum. The major importing countries of India guar products are Europe, USA, China, UK, South Africa and Japan.

It is well known that weeds are ubiquitous but their presence in cropped area particularly in rainy season crops like vegetable clusterbean act as major limiting factor in achieving potential harvest. Inadequate weed control is one of the main factors related to decrease in clusterbean production. In India, farmers rely predominantly on mechanical manual methods of weed control. But, these practices alone do not ensure weed free conditions and are expensive, cumbersome and timeconsuming too and further reducing the profit margin. Vegetable clusterbean crop is cultivated mainly in the north-western part of country during kharif and summer season where inadequate weed management is a major constraint in harnessing its production potential. Yield reduction due to weed infestation is to the tune of $53.7 \%$ has been observed (Saxena et al., 2004). Hence, the present investigation was undertaken to find out an effective and economical viable weed management practices for summer cluster bean.

\section{Materials and Methods}

A field experiment was conducted at Agriculture Research Sub Station, Kotputli, Jaipur, Sri Karn Narendra Agriculture University, Jobner, Jaipur during the kharif 2017 and 2018. Seven treatments comprising pendimethalin@1.0 kg ai. per hectare as pre emergence, pendimethalin @ 1.0 kg ai.per hectare as pre emergence with one hand weeding at 25 days after sowing, imazathyper 10 SL@ $40 \mathrm{~g}$ a.i. per hectare at 15-20 days after sowing, quazilfop ethyl @ $37.5 \mathrm{~g}$ a.i.per hectare 15-20 days after sowing, hand weeding at 20 and 40 days after sowing, weed free and unweeded control were tried in randomized block design with four replications. Gross and net plot size was 4.80 $\mathrm{m} \times 2.70 \mathrm{~m}$ and $3.60 \mathrm{~m} \times 1.80 \mathrm{~m}$, respectively. Cluster bean variety $\mathrm{M}-83$ was sown with recommended package of practices except weed management. Fertilizers were applied @ $20 \mathrm{~kg} \mathrm{~N}$ and $40 \mathrm{~kg} \mathrm{P}_{2} \mathrm{O}_{5}$ per hectare uniformly through urea and DAP. Data on weed growth and yield performance were recorded.

\section{Results and Discussion}

Weed flora of experimental field comprised Cynodon dactylon, Cyperus rotundus, Echinochloa colona, Echinochloa crus-galli among monocot weeds and Amaranthus viridis, Amaranthus spinosus, Commelina 
benghalensis, Parthenium hysterophorus and Trianthema portulacastrum among dicot weeds.

The minimum dry weight of weed was recorded in two hand weeding at 20 and 40 DAS $(261.63 \mathrm{~kg} / \mathrm{ha})$ followed by Pendimethalin @ $1.0 \mathrm{~kg}$ ai./ha as pre emergence \& one hand weeding at 25 DAS $(281.25 \mathrm{~kg} / \mathrm{ha})$ and then Imazathyper 10 SL@ $40 \mathrm{~g}$ ai./ha at $15-20 \mathrm{DAS}(301.75 \mathrm{~kg} / \mathrm{ha})$ on pooled basis of data of both the years. However, the maximum dry weight was recorded in weedy check $(1476 \mathrm{~kg} / \mathrm{ha})$

On the basis of pooled data, the highest green pod yield was recorded in weed free $(44.53 \mathrm{q} / \mathrm{ha})$ and the lowest was under unweeded check $(21.03 \mathrm{q} / \mathrm{ha})$. The yield loss due to uncontrolled growth of weeds as compared to weed free. The data revealed that the maximum green pod yield was recorded in weed free $(44.53 \mathrm{q} / \mathrm{ha})$ followed by treatment two hand weeding at 20 and 40 DAS (44.06 q/ha), Pendimethalin @ $1.0 \mathrm{~kg}$ ai./ha as pre emergence \& one hand weeding at 25 DAS
(43.41 q/ha) and Imazathyper 10 SL@ $40 \mathrm{~g}$ ai./ha at $15-20$ DAS (42.98 q/ha), respectively. All these treatments remains at par with each other in this study. This might be due to effective and efficient control of weeds by integration of hand weeding and pre-emergence and post emergence of herbicides.

The highest net returns (Rs. 85948/ha) was obtained under treatment Imazathyper 10 SL@ $40 \mathrm{~g}$ ai./ha at 15-20 DAS which was significantly at par with Pendimethalin @ 1.0 $\mathrm{kg}$ ai./ha as pre emergence \& one hand weeding at 25 DAS and Hand weeding at 20 and 40 DAS. Similarly, highest B:C ratio (3.0) was recorded in Imazathyper 10 SL@ 40 $\mathrm{g}$ ai./ha at 15-20 DAS which was significantly higher than other treatments. The higher benefits obtained under these treatments were also due to comparatively less cost of herbicides than hand weeding as well as higher seed and stover yield of cluster bean. These finding are in agreement with those of Reager et al., (2003), Saras et al., (2014), Yadav et al., (2011) (Fig. 1-3 and Table 1-3).

Table.1 Weed growth and yield of vegetable cluster bean as influenced by weed management treatments

\begin{tabular}{|c|c|c|c|c|c|c|}
\hline \multirow[t]{2}{*}{ Treatment } & \multicolumn{3}{|c|}{$\begin{array}{c}\text { Dry weight } \\
\text { of weeds (kg/ha) }\end{array}$} & \multicolumn{3}{|c|}{$\begin{array}{l}\text { Green pod } \\
\text { yield (q/ha) }\end{array}$} \\
\hline & 2017 & 2018 & Pooled & 2017 & 2018 & Pooled \\
\hline$T_{1}:$ Weedy check & 1545 & 1407 & 1476 & 19.23 & 22.83 & 21.03 \\
\hline$T_{2}:$ Hand weeding at 20 and 40 DAS & 241.25 & 282 & 261.625 & 42.73 & 45.40 & 44.06 \\
\hline $\begin{array}{l}T_{3}: \text { Pendimethalin @ } 1.0 \mathrm{~kg} \text { ai./ha as } \\
\text { pre emergence }\end{array}$ & 576 & 648 & 612 & 33.13 & 36.13 & 34.63 \\
\hline $\begin{array}{l}\mathrm{T}_{4}: \text { Pendimethalin @ } 1.0 \mathrm{~kg} \text { ai./ha } \\
\text { as pre emergence } \& \text { one hand } \\
\text { weeding at } 25 \mathrm{DAS}\end{array}$ & 268.75 & 293.75 & 281.25 & 41.73 & 45.08 & 43.41 \\
\hline $\begin{array}{l}T_{5}: \text { Imazathyper } 10 \text { SL@ } 40 \mathrm{~g} \text { ai./ha } \\
\text { at 15-20 DAS }\end{array}$ & 282.25 & 321.25 & 301.75 & 41.40 & 44.57 & 42.98 \\
\hline $\begin{array}{l}\mathrm{T}_{6}: \text { Quazilfop ethyl @ } 37.5 \mathrm{~g} \text { ai./ha } \\
\text { 15-20 DAS }\end{array}$ & 495 & 559 & 527 & 36.83 & 39.63 & 38.23 \\
\hline $\mathbf{T}_{7}:$ Weed free & 0 & 0 & 0 & 42.94 & 46.12 & 44.53 \\
\hline S.Em \pm & 12.98 & 6.69 & 7.30 & 0.90 & 0.75 & 0.59 \\
\hline C.D. $(5 \%)$ & 38.58 & 19.87 & 20.95 & 2.66 & 2.24 & 1.68 \\
\hline
\end{tabular}


Table.2 Economic feasibility of different weed management treatment on vegetable cluster bean

\begin{tabular}{|c|c|c|c|c|c|c|c|c|c|}
\hline \multirow[t]{2}{*}{ Treatment } & \multicolumn{3}{|c|}{ Gross returns (Rs./ha.) } & \multicolumn{3}{|c|}{ Net returns (Rs./ha.) } & \multicolumn{3}{|c|}{ B:C ratio } \\
\hline & 2017 & 2018 & Pooled & 2017 & 2018 & Pooled & 2017 & 2018 & Pooled \\
\hline$T_{1}:$ Weedy check & 57690 & 68490 & 63090 & 17690 & 28490 & 23090 & 1.44 & 1.71 & 1.58 \\
\hline $\begin{array}{l}T_{2}: \text { Hand weeding at } 20 \\
\text { and } 40 \text { DAS }\end{array}$ & 128175 & 136200 & 132188 & 78175 & 86200 & 82188 & 2.56 & 2.72 & 2.64 \\
\hline $\begin{array}{l}\mathrm{T}_{3} \text { : Pendimethalin @ } \\
0.5 \mathrm{~kg} \text { ai./ha as pre } \\
\text { emergence }\end{array}$ & 99390 & 108390 & 103890 & 57390 & 66390 & 61890 & 2.37 & 2.58 & 2.47 \\
\hline $\begin{array}{l}\mathrm{T}_{4}: \text { Pendimethalin @ } \\
1.0 \mathrm{~kg} \text { ai./ha as pre } \\
\text { emergence } \& \text { one hand } \\
\text { weeding at } 25 \mathrm{DAS}\end{array}$ & 125190 & 135240 & 130215 & 78190 & 88240 & 83215 & 2.66 & 2.88 & 2.77 \\
\hline $\begin{array}{l}T_{5}: \text { Imazathyper } 10 \\
\text { SL@ } 40 \mathrm{~g} \text { ai./ha at } 15 \text { - } \\
20 \text { DAS }\end{array}$ & 124185 & 133710 & 128948 & 81185 & 90710 & 85948 & 2.89 & 3.11 & 3.00 \\
\hline $\begin{array}{l}T_{6}: \text { Quazilfop ethyl @ } \\
37.5 \text { g ai./ha 15-20 DAS }\end{array}$ & 110490 & 118890 & 114690 & 68490 & 76890 & 72690 & 2.63 & 2.83 & 2.73 \\
\hline $\mathbf{T}_{7}:$ Weed free & 128820 & 138360 & 133590 & 74820 & 84360 & 79590 & 2.39 & 2.56 & 2.47 \\
\hline S.Em \pm & 2690 & 2262 & 1757 & 2690 & 2262 & 1757 & 0.06 & 0.05 & 0.04 \\
\hline C.D. (5\%) & 7991 & 6722 & 5040 & 7991 & 6722 & 5040 & 0.17 & 0.15 & 0.11 \\
\hline
\end{tabular}

Table.3 Effect of different weed management treatment on weed index and weed efficiency on vegetable cluster bean

\begin{tabular}{|l|c|c|c|c|c|c|}
\hline \multirow{2}{*}{ Treatment } & \multicolumn{3}{|c|}{ Weed index } & \multicolumn{3}{c|}{ Weed control efficiency } \\
\cline { 2 - 7 } & 2017 & 2018 & Pooled & 2017 & 2018 & Pooled \\
\hline $\mathbf{T}_{\mathbf{1}}:$ Weedy check & 55.22 & 50.50 & 52.77 & - & - & - \\
\hline $\begin{array}{l}\mathbf{T}_{\mathbf{2}}: \text { Hand weeding at 20 and } \\
\mathbf{4 0} \text { DAS }\end{array}$ & 0.50 & 1.56 & 1.05 & 84.39 & 79.96 & 82.27 \\
\hline $\begin{array}{l}\mathbf{T}_{\mathbf{3}}: \text { Pendimethalin @ 0.5 kg } \\
\text { ai./ha as pre emergence }\end{array}$ & 22.85 & 21.66 & 22.23 & 62.72 & 53.94 & 58.54 \\
\hline $\begin{array}{l}\mathbf{T}_{\mathbf{4}}: \text { Pendimethalin @ 1.0 kg } \\
\text { ai./ha as pre emergence \& } \\
\text { one hand weeding at 25 DAS }\end{array}$ & 2.82 & 2.25 & 2.53 & 82.61 & 79.12 & 80.95 \\
\hline $\begin{array}{l}\mathbf{T}_{\mathbf{5}}: \text { Imazathyper 10 SL @ 40 } \\
\text { gai./ha at 15-20 DAS }\end{array}$ & 3.60 & 3.36 & 3.48 & 81.73 & 77.17 & 79.56 \\
\hline $\begin{array}{l}\mathbf{T}_{\mathbf{6}}: \text { Quazilfop ethyl @ 37.5 g } \\
\text { ai./ha 15-20 DAS }\end{array}$ & 14.23 & 14.07 & 14.15 & 67.96 & 60.27 & 64.30 \\
\hline $\mathbf{T}_{\mathbf{7}}:$ Weed free & 0.00 & 0.00 & 0.00 & 100.00 & 100.00 & 100.00 \\
\hline
\end{tabular}


Fig.1 Dry weight of vegetable cluster bean as influenced by weed management treatments

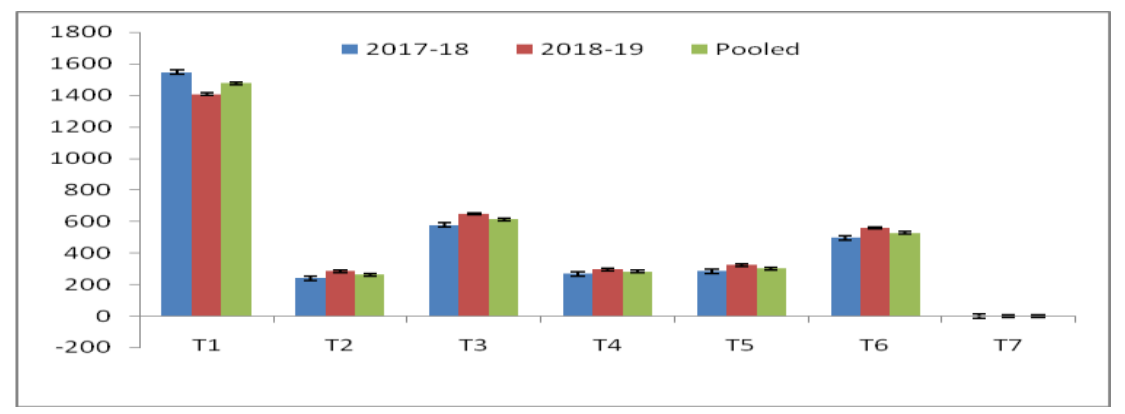

Fig.2 Green pod yield of vegetable cluster bean as influenced by weed management treatments

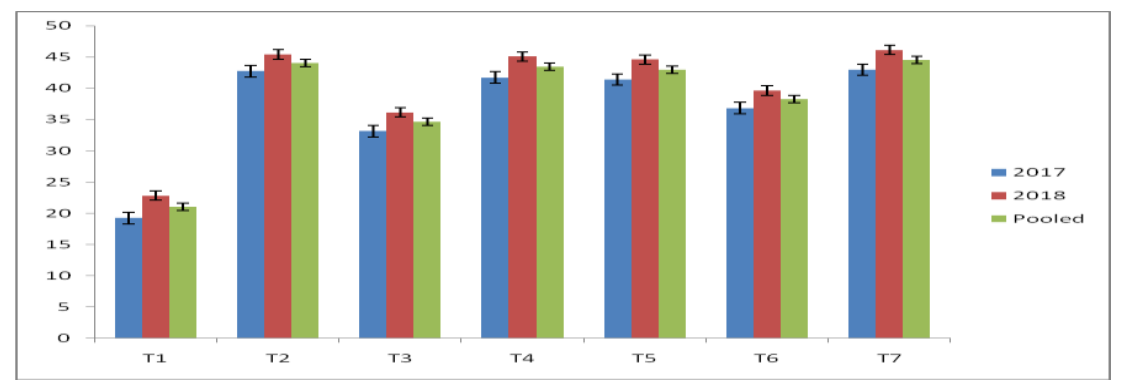

Fig.3 Economic feasibility of different weed management treatment on vegetable cluster bean

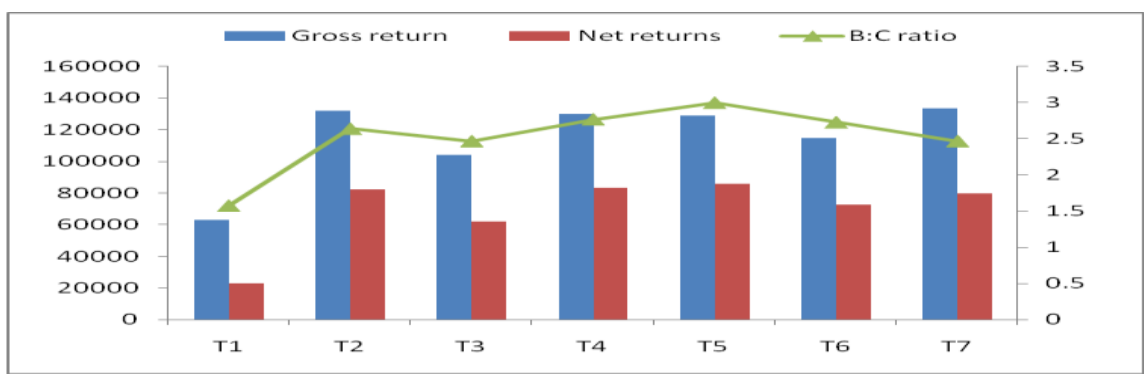

On the basis of pooled data of both the years, the minimum weed index was observed in Hand weeding at 20 and 40 DAS followed by Pendimethalin @ $1.0 \mathrm{~kg}$ ai./ha as pre emergence \& one hand weeding at 25 DAS and Imazathyper 10 SL@ $40 \mathrm{~g}$ ai./ha at 15-20 DAS while highest weed index was found in Treatment weedy check. The maximum weed control efficiency was recorded in weed free treatment followed by Hand weeding at 20 and 40 DAS, Pendimethalin @ $1.0 \mathrm{~kg}$ ai./ha as pre emergence $\&$ one hand weeding at 25 DAS and Imazathyper 10 SL@ $40 \mathrm{~g}$ ai./ha at 15-20 DAS. The lowest weed control efficiency was recorded in treatment Pendimethalin @ $0.5 \mathrm{~kg}$ a.i./ha as pre emergence

It can be concluded that maximum net returns and benefit : cost ratio in clusterbean could be realized with the integrated application of imazethapyr $100 \mathrm{~g} / \mathrm{ha}$ at $20 \mathrm{DAS}+$ one hand weeding at 35 DAS under sub humid southern plain and Aravalli hills zone of Rajasthan (Hemraj Dhaker et al 2009). Among different herbicides imazethapyr $60 \mathrm{~g}$ at $20 \mathrm{DAS}$ showed highest values of yield in cluster bean (Godara and Ravindra, 2015). 
On the basis of the results of the present two year field study, it can be concluded that effective and economically viable weed management in vegetable cluster bean on clayey soil can be achieved by application of imazathyper10 SL@40 g ai./ha at days after sowing Alternatively, maintaining the crop weed free throughout crop growth period OR adopting spray of Pendimethalin @ $1.0 \mathrm{~kg}$ ai./ha as pre emergence \& one hand weeding at 25 DAS days after sowing can be employed according to availability of labours.

\section{References}

Anonymous (2020). Agricultural and Processed Food Products Export Development Authority. (Source: http://apeda.govt.in).

Anonymous (2015). Published in Agricultural Statistics at a Glance, Ministry of Agriculture, GOI (New Delhi), p: 19.

Dhaker, H., Mundra, S.L. and Jain, N.K. (2009). Weed management in clusterbean [Cyamopsis tetragonoloba (L.) Taub.]. Indian J. Weed Sci., 41:224-227.

Godara A.S. and Ravindra Singh. Legume Research An International Journal 2015 (38): 415-418.

Hemraj Dhaker, S. L. Mundra and N. K. Jain Weed Management in Clusterbean [Cyamopsis tetragonoloba (L.) Taub.] Indian J. Weed Sci. 41 (3 \& 4): 224-227
(2009)

Nagaraj Meda. Mapping the market thought of guar and guargum markets. Paper presented in the Guar International Conference-2013 held on 6 to 7 th at Jaipur Marriott Hotel, Jaipur, India. 2013.

(source:

www.guarinternational.com).

Reager ML, Choudhary GR, Dahama AK. Effect of weed control and phosphorus on growth and quality of cluster bean (Cyamopsis tetragonoloba L.). Ann. Agric. Res. New Series. 2003b; 24 (3):563-566.

Saras P, Patel BD, Parmar SK. Weed management by cultural and chemical practices and their effect on phytotoxicity and growth, quality and yield parameters of cluster bean (Cyamopsis tetragonoloba (L.) Taub). Trends in biosciences. 2014; 7(24):4196-4199.

Saxena A, Singh YV, Singh R. Crop weed competition in cluster bean in arid region. Journal of Arid Legumes. 2004; 1:41-43.

Yadav SL, Kaushik MK, Mundra SL. Effect of weed control practices on weed dry weight, nutrient uptake and yield of cluster bean [Cyamopsis tetragonoloba (L.) Taub.] under rainfed condition. Indian Journal of Weed Science. 2011; 43(1, 2): 81-83.

\section{How to cite this article:}

Dinesh K. Yadav, P. Deewan, Yogendra Meena, Deepak Gupta, S. M. Yadav and Manju Netwal. 2021. Weed Management in Vegetable Cluster Bean (Cyamopsis tetragonoloba). Int.J.Curr.Microbiol.App.Sci. 10(02): 2821-2826. doi: https://doi.org/10.20546/ijcmas.2021.1002.313 